\title{
Development of Biography Text Learning Materials Based on Contextual Approach to Students Class $\mathrm{X}$ of Senior High School
}

\author{
Ririn Susmita \\ Indonesian Language Education and Literature \\ State University of Medan \\ Medan, Indonesia \\ Corresponding email: ririnsusmita1212@gmail.com
}

\author{
Wisman Hadi \\ Indonesian Language Education and Literature \\ State University of Medan \\ Medan, Indonesia
}

\author{
Abdurahman Adisaputera \\ Indonesian Language Education and Literature \\ State University of Medan \\ Medan, Indonesia
}

\begin{abstract}
This study aims to produce a biography text teaching materials based on contextual approach on students class $X$ of Senior High School. The research method used was research development method of Research and Development ( $R$ \& D) refers to Borg and Gall model. The stages of development were preliminary study stage, initial product development and product trial. Product development through the validation of material experts and design experts. Expert material validation results included the feasibility of the content with an average of $\mathbf{8 8 . 2 8 \%}$ with very good category, the feasibility of presentation with an average of $85.57 \%$ with very good category, and the assessment of the language with an average of $89.42 \%$ with very good category. The results of design validation of teaching materials with an average of $88.75 \%$ with very good category. Product trial was conducted in three stages: individual trials, small group trials and limited field trials. Individual trials with an average of $81.94 \%$ with very good category, small group trials with an average of $85.41 \%$ with very good category and limited field trials with an average of $88.15 \%$ with very good category. The effectiveness of teaching materials was obtained through student learning outcomes during pretest and postest. Average score during pretest 65.62 and at postest 78.59 . This proves that the biography text teaching material based on contextual approach is feasible, easy and effective to be used in learning in class $X$ of senior high school. This study has implications for improving student learning outcomes in writing biography texts using teaching materials based on contextual approach.
\end{abstract}

Keywords-- development of teaching materials; biography text; contextual-based approach

\section{INTRODUCTION}

Teachers as educators are tasked with managing and developing learning resources as contained in Law Depdiknas No. 20 year 2003 explained that the teacher's obligation before standing in front of the class is to create an educational atmosphere that are creative, dynamic, dialogical, and has a professional commitment to improve the quality of education, regardless of whether the government has provided learning books, teacher books, syllabi, and teacher manuals [1]. In this case, teachers must be able to make teaching materials needed by students in the learning process. But in reality teachers do not understand how the principles of teaching materials are developed and how to develop them. This is supported by previous research by Putra et al. (2014), that not all teachers are able to develop even compile teaching materials independently [2]. Mudlofir (2011) defined teaching materials as all forms of material used to assist in the learning process [3]. The teaching materials are compiled in a coherent and systematic manner both written and unwritten. Educators have so far relied on available textbooks or student worksheets that have been circulating in schools, without modifying it in advance.

Based on the results of interview obtained from Indonesian language teachers in Senior High School PAB 01 Medan Estate, named Fitri Hayani, S. Pd, it was known that the teaching materials used in the learning process only used on type of teaching materials as the primary source produced by Kemendikbud, namely a teaching material entitled "Bahasa Indonesia." Then, she stated, the results of students writing learning results were still low, there were students who did not acquire completion score based on minimum criteria of mastery determined by the school, which was 75 . In this case, it was caused by the teachers who were still using noninteresting teaching materials, the process of learning were still focusing on teachers and textbooks which only provided by the government. In the activity of learning, teachers should delop tex teaching materials that can motivate and interesting for students. Students would have been easier to study by using textbooks, in reality textbooks used by students until recently are still making them confused in understanding them. The statement is supported by data obtained by Nurwanti et al. (2015), that teaching materials used by teachers are only textbooks published by publishers that have 
not been adjusted with the learning needs and characteristics of students [4].

Indonesian language material learned in class $\mathrm{X}$ of senior high school is biographical text. Kemendikbud (2017) A biography is a story or information about a person's life [5]. A biography is more complex than just a list of birth or death dates and someone's work data. Regarding the biographical text material contained in the student book, the researcher traced further and analyzed the contents of the biographical material in the student book entitled "Indonesian Language" obtained the results that there were three biographical texts entitled 1) BJ Habibie 2) George Saa, Si Jenius dari Papua 3) Komikus Indonesia Yang Mendunia, Ardian Syaf. The three texts aim to enable students to understand and enrich their insights and as role models so that they can live their lives well and fill life with works that are beneficial not only for themselves, but also for other people from the figures in Indonesia, but it also becomes not relevant if viewed from the needs of students in supporting understanding of the characters in their area. Therefore, for learning resources to be easily understood based on the context in their environment, it is necessary to develop teaching materials that are relevant to students' needs, it is felt by students of class X Senior High School 01 Medan Estate who must take minimum criteria of mastery 75. According to some students from the school, in learning biographical texts students did not understand how the overall structure of the texts presented in the book. There was no introduction to providing an understanding of the biography text as initial information.

Minimum criteria of mastery set by the school in Indonesian language with a score of 75.00. However, after field observations, the average score of students in class VIIIC was 69.72 and only 11 students from 36 students achieved completeness. There were 25 students who were not complete in compiling biographical texts. in previous research conducted by Angela Klaudia Danu (2015) described a number of causes of meaninglessness in value education, namely (1) teacher teaching patterns are still connectiveoriented, (2) teacher quality and dedication is still not optimal, (3) value poisoning occurs in the community as a reference in behavior, and (4) the availability of teaching materials that do not reflect the value education experience [6].

The problems described above show students need something that is contextual. Therefore, contextual approach can be an alternative in learning. This is done by entering the concept of contextual approache into teaching materials. For this reason, it is necessary to develop biography text teaching materials based on contextual approaches.

The purpose of this development research is to describe the process of developing biography text teaching materials based on the contextual approach, describing the feasibility of biography text teaching materials based on contextual approach, and describing student learning outcomes after using biographical text teaching materials based on contextual approach.

\section{METHOD}

This research was conducted at Senior High School PAB 01 Medan Estate located at Jln. Mesjid No. 1, Medan Estate, Kec. Percut Sei Tuan, Kab. Deli Serdang. The research will be carried out in April to June 2018. This research and development population were students class X of Senior High School PAB 01 Medan Estate. The researcher took a sample of 32 students. This type of research is Research and Development. Tegeh et al (2014), development research is a research method that is effective enough to improve learning practices, with the aim of developing new products or improving existing products so that they can be accounted for [7]. This study refers to Borg and Gall's research model. The instruments used in this study to collect data were grouped into 3 types, namely: (1) validation instrument of the material and design expert team on teaching materials, (2) instruments of student and teacher responses to teaching materials consisting of individual trials, small group trials, limited field trials, and responses from Indonesian language teachers, and (3) tests of student learning outcomes, the instrument was in a form an essay test. Assessment instruments for validators and individual trials, small groups and limited field groups were made in the form of a Likert scale that has been given a score, then the data was analyzed quantitatively descriptive.

\section{RESULTS AND DISCUSSION}

\section{A. Teaching Material Development Process}

The first step was a preliminary study. Preliminary study was carried out to understand ideas so that the products developed were in accordance with needs. The preliminary study was carried out by distributing questionnaires to teachers and students, namely questionnaires of teacher needs and questionnaires for student needs.

As much as $66.67 \%$ of teachers considered biographical text material in textbooks not easily taught to students. This means that teachers still had difficulty applying the contents of textbooks in learning. Of the 3 teachers who were given questionnaires, only 1 teacher $(33.33 \%)$ claimed to know module-based teaching materials. This further strengthened the data that there was no supporting teaching material in Indonesian language learning in the school. As much as $81.25 \%$ of students also never knew about module-shaped teaching materials. One problem was that $62.5 \%$ of students experienced difficulties in learning biographical texts. They were still encountering difficulties to understand biographical texts in the test book.

\section{B. Feasibility of Teaching Materials}

Validation of instructional materials was carried out by material experts and design experts by assessing each aspect as a whole. The results of module validation by material experts based on the content feasibility assessment showed that the average percentage of aspects of material suitability assessment with $\mathrm{KI}$ and $\mathrm{KD}$, material accuracy, material updates and curiosity was $88.28 \%$ with the criteria of "very 
good". The results of module validation by material experts based on the presentation feasibility assessment showed that the average percentage of aspects of the presentation techniques, presentation of learning and presentation completeness was $85.57 \%$ with the criteria of "very good". The results of module validation by material experts based on language feasibility assessment indicate that the average percentage of assessment aspects was straightforward, communicative, dialogical and interactive, suitability with the level of development of students, the clarity and integration of the flow of thought and the use of terms, symbols and icons was $89.42 \%$ with criteria "very good".

The results of the module validation by the design expert based on the graphical feasibility assessment (design) showed that the average percentage of module size assessment aspect, module cover design and module content design was $88.75 \%$ with the criteria of "very good".

The assessment of the response of the Indonesian language teacher to the biography text module based on the contextual approach was carried out by three teachers, Fitri Hayani, S.Pd., Drs. Umar Dhani and Emilya Wahyuningsih, S, Pd. who were teachers at Senior High School PAB 01 Medan. The results of the teacher's response to the biographical text module based on the contextual approach developed had an average percentage of $87.78 \%$ with the criteria "very good".

Individual trials were conducted on three students. The purpose of this trial was to identify product deficiencies and student responses to the developed teaching materials. The results of the individual trial evaluation concluded that the biographical text module based on the contextual approach was included in "very good" criteria with an average percentage of $81.94 \%$.

Small group trial was conducted on 9 students. The purpose of this small group trial was to re-know the students' responses to the module after being revised at the individual trial stage. The results of the small group trial of the module showed an average percentage of $85.41 \%$ with the criteria "very good". Limited field trial was conducted on 32 students. The results of students' responses to the module based on contextual approach to limited field trial will later be used to see the practicality aspects of the module as a whole. The results of limited field trial showed an average percentage of 88.15 with the criteria "very good".

\section{Student Learning Results}

The average value (mean) of student learning outcomes through pretest was 65.62 and posttest was 78.59. Based on these results it can be seen that the average value of student learning outcomes increased with a difference of 12.97. Student learning outcomes of writing biographical texts through pretest had the lowest score of 60 and the highest score of 75 , while the learning outcomes of students writing biographical text through postest had the lowest score of 70 and the highest score of 85 .

\section{CONCLUSION}

Based on the objectives, the results of the research on the development of teaching materials for biographical text based on a contextual approach to students class X of Senior High School PAB 01 Medan Estate presented earlier are described below:

1. The process of developing biography text teaching material based on a contextual approach is carried out in three stages: preliminary studies, initial product development and product trials. In the preliminary study phase data obtained that students and teachers need companion of teaching materials that are appropriate to the student's environmental context. In the initial product development stage, product design and product validation are carried out by material experts and design experts. The results of the assessment is feasible to be tested. The product testing phase was carried out with three stages, namely individual trials, small groups and limited fields. Individual trials obtained an average percentage of $81.94 \%$ with the criteria of "very good". Small group trial obtain an average percentage of $85.41 \%$ with the criteria of "very good". Limited field trial obtain an average percentage of $88.15 \%$ with the criteria of "very good". Based on these data it appears that the development of teaching materials is in accordance with the development research process.

2. Teaching materials for biographical texts based on contextual approach is eligible to meet the requirements for use in Indonesian language learning. Feasibility of teaching materials is obtained from the results of the validation of two material experts and two design experts. The results of the material expert validation include content eligibility with an average percentage of $88.28 \%$ in "very good" criteria, presentation eligibility with an average percentage of $85.57 \%$ in "very good" criteria, language assessment with an average percentage of 89,42 on "very good" criteria and graphic feasibility with an average percentage of $88.75 \%$ in the criteria of "very good".

3. Student learning outcomes after using biography text teaching materials based on contextual approach is better than before using biographical text teaching materials based on contextual approaches. Student learning outcomes after using biography text module based on contextual approach increased by 12.97 with an average pretest of 65.62 and a posttest average of 78.59 .

\section{REFERENCES}

[1] Depdiknas, Undang-undang RI No. 20 Tahun 2003. Tentang Sistem Pendidikan Nasional. Jakarta: Depdiknas, 2003.

[2] Putra, I. K. et al., "Pengembangan Bahan Ajar Bahasa Indonesia Pada Topik Teks Laporan Teks Hasil Observasi Berbasis Tri Hita Karana untuk Siswa Kelas VII SMP Negeri 1 Gianyar Bali”. Jurnal Pendidikan Bahasa, vol. 3, 2014.

[3] Mudlofir, A., Aplikasi KTSP dan Bahan Ajar dalam Pendidikan Islam. Jakarta: Raja Wali Pers, 2011, pp. 128.

[4] Nurwanti, et al., "Pengembangan Modul Bahasa Indonesia Berbasis Life Skills untuk Kelas X SMK di Kota Metro. Magister Pendidikan Bahasa dan Sastra Indonesia”. J-Simbol (Bahasa, Sastra, dan Pembelajarannya), 2015. 
[5] Kemendikbud, Buku Guru: Bahasa Indonesia. Jakarta: Kemendikbud, 2017.

[6] Danu, A. K., "Pengembangan Bahan Ajar Teks Biografi Berbasis Pendidikan Nilai dalam Pembelajaran Bahasa Indonesia untuk Kelas VII/2 SMP Negeri 2 Macang Parai, Manggarai Barat, Nusa Tenggara Timur". Jurnal NOSI, vol. 3, 2015.

[7] Tegeh, I M., et al., Model Penelitian dan Pengembangan. Yogyakarta: Graha Ilmu, 2014. 